\title{
MICROPLASTICS RISK AT THE INTERFACE OF CIRCULAR ECONOMY, QUALITY AND FOOD SAFETY IN POLAND: A CASE STUDY
}

\author{
Piotr KAFEL $\mathbb{1 D}^{*}$, Paweł NOWICKI ${ }^{\circledR}$, Urszula BALON® \\ Department of Quality Management, Cracow University of Economics, Krakow, Poland
}

Received 21 May 2020; accepted 29 April 2021

\begin{abstract}
The purpose of this paper is to explore the scope of undertaken and planned actions related to microplastics risk in one of the biggest polish food sector company for better understanding the relations between quality management, food safety management and circular economy. To explore the planed and undertaken actions in relation to microplastics risk a case study was performed. It was performed in one of the leading polish organization producing and selling food products of an international range of operation. During the study representative of the leadership of the organization was interviewed as well as relevant instructions and records provided by the organization were analysed. Results indicate that the issue of microplastics for studied company is a marginal problem, that has not been given much attention so far. On the other hand, significant changes at the global level such as circular economy strategy lead to changes in the design of products (mainly packaging). To the best of the authors' knowledge, this is the first study to examine the microplastics risk from the perspective of the management systems implemented in food sector organization with the circular economy context. This study enriches current knowledge about circular economy and its integration with other management systems in the microplastics elimination context.
\end{abstract}

Keywords: microplastics, circular economy, management standard, food safety, ISO 9001, HACCP, sustainability.

JEL Classification: Q56, L23, M11.

\section{Introduction}

Plastics is a generic term that is used in the case of polymeric materials. That materials usually contain other substances to improve performance and/or reduce costs (EASAC, 2020). Microplastics is a term that generally is considered as a small particles of plastics. However, there is no clear definition indicating the size and composition of the microplastic. Often the division due to the size of the particles is bellow $5 \mathrm{~mm}$ for microplastics and $0.1 \mathrm{~mm}$ for nanopalstics (EASAC, 2020). Microplastics can be categorized into primary and secondary types. Primary microplastics are the one that originally were produced smaller than $5 \mathrm{~mm}$ in size, while secondary ones results from the divisions of larger items into smaller ones (Lusher et al., 2017).

The recent discussion concerning a microplastics risk is gaining more and more attention nowadays. The production of the plastics in the world is rapidly growing. Parallel, the results of the plastics waste management is still unsatisfactory. In 2014 year, 25.8 million tons of generated by consumers plastics waste ended up in the officially reported waste streams in the European Union. The greatest percentage of plastics waste was used as food and drink packaging materials. Only $29.7 \%$ of all postconsumer type of plastic waste has been recycled, 39.5\% was energetically recovered while $30.8 \%$ still end up on landfills (EU, 2018).

There are some studies concerning the occurrence of microplastics in the environment, both in the plants and animals. It is a direct risk that the microplastics is present in food and beverages designed for human consumption.

The reduction of plastic waste and in consequence the slowing down the migration of microplastic to the environment is one of the goals of the circular economy practices recommended by EU authorities. Due to the current changes in legislation, the organization's efforts towards a more circular economy practices seems to be inevitable.

Within the lack sound reliable knowledge about the potential human health impacts and the alarming information's about the microplastics pollution in the media and some environmental groups, it is interesting how, organizations that have implemented quality and food safety management systems are dealing with the problem. The

${ }^{*}$ Corresponding author. E-mail: kafelp@uek.krakow.pl 
requirements of food safety system concentrate mostly on the products, so the risks for the health should be considered. Quality management system is more focused on the consumer satisfaction and should deal rather with the fears of the customers. The circular economy practices are focused on the more sustainable activities. The circular economy is an approach that replaces the concept of "endof-life". As a principle, the use of renewable energy sources should be maximized and elimination of toxic chemicals usage which make it difficult or impossible to reuse (Nowicki et al., 2020).

One of the main sources that develops and describes circular economy in the European Union is the document provided by Ellen MacArthur Foundation (EMF). The circular economy focuses primarily on (Ellen MacArthur Foundation (EMAF), 2015):

- weight reduction - limitation of materials used to provide a specific service - (this aspect applies, for example, to the packaging of food products),

- efficiency - efficiency increase of energy and materials consumption at the stages of production and use,

- substitution - reduction the usage of hazardous or/ and difficult to recycle materials - (this aspect may apply to risk of microplastics presence in the food products).

Reduction of plastics used as well as an increase of plastic materials reuse are the goals that can lead to reduction of microplastics introduced into the environment and consequently to the food itself. Moreover the circular economy concept is one of the foundation of The European Green Deal strategy implemented by EU countries (EU, 2019).

The goal of the article is to explore the scope of planned and already undertaken activities related to microplastics risk in food sector, from the perspective of the food producing organization. More specifically, an attempt to determine which of the analyzed systems is mostly related to the activities related to microplastics. The circular economy as a concept for global perspective was associated with food safety and quality management systems perspectives which refer to standardized procedures and activities on the level of an organization.

\section{Literature review: Microplastics and management systems in organizations}

\subsection{Pollution of microplastics in the environment}

The widespread use of the plastics is dated for the 1950s. Since that time it was developed and changed multiple times in composition, manufacturing processes and practical applications (EASAC, 2020). It can be assumed that in parallel with the beginning of the production and use of plastic, first microplastics environmental pollution derived from decomposition processes.

In the early seventies one the first report concerning microplastics pollution in the coastal waters of Atlantic has been published (Carpenter et al., 1972). The presence of pollution on microplastics is reported in polar waters (Cozar et al., 2014; Goldstein et al., 2012) and marginal seas and coastal waters (Isobe et al., 2014, 2015; Lusher et al., 2014). Research results have also indicated the presence of microplastics in organisms living in the most isolated, inaccessible and deepest areas of the Earth's oceans such as the Marian ditch (Jamieson et al., 2019). There are assumption to model the amount of the microplastics in the waters that predict a fourfold increase of particles by 2060 from the current state (Isobe et al., 2019). Moreover even if humans will stop production of plastic, the amount of it that is already existing in the marine environment and its transformation into secondary microplastics will cause its continuous increase (Lusher et al., 2017).

Considering the air pollution, a main source of microplastics are plastic fibers which represent approximately $16 \%$ of the world plastic production (Gasperi et al., 2018). The micro fibers were detected both in the outdoor and indoor environment (Dris et al., 2017; Dris et al., 2016). There are also studies that illustrate the presence of microplastics in both urban and nonurban atmospheric fallout (Allen et al., 2019; Bergmann et al., 2019; Cai et al., 2017; Dehghani et al., 2017; Dris et al., 2016). Without a doubt, microplastics is detectable in air but it is still a new area of research and some concerns about the accuracy of the existing methods. According to Wesch et al. (2017) pollution levels by microfibers have been overestimated and real pollution may be lower.

The presence of pollution in water and air clearly indicates the presence of microplastics in soil. Also the agricultural activities such as usage of plastic mulch films increase the plastic residues in soil (Liu et al., 2014; Steinmetz et al., 2016). Thus is affecting vegetative and reproductive growth of plants and will have bigger impact in the long term perspective (Qi et al., 2018; Steinmetz et al., 2016).

\subsection{Microplastics in food}

Plastic particles are contaminating the ecosystems and the whole food chain, including primary and secondary food ingredients intended for consumption (Lusher et al., 2017). Due to the most frequent and recognize occurrence of microplastics in waters, the largest number of studies relates to issue in a seafood (Smith et al., 2018).

There are some evidences that microplastics occurs also in other food products. Studies have shown the possibility of plant accumulating very microplastics from polluted soil (Li et al., 2019).

According to the Schymanski et al. research (2018), microplastic was detected in water from all tested in the study plastic bottles (both returnable and single-use), as well as in glass bottles and beverage cartons sourced from grocery stores. The main root cause of the microplastics in the food was the migration from the packaging. Taking into consideration the size of the particles, almost $80 \%$ of 
all found materials had a particle size from 5 to $20 \mathrm{~mm}$. Those results are in line with other studies that indicate the contamination of beverages such as beer as well as in tap water or sea salt (Kosuth et al., 2018).

\subsection{Impact of the microplastics on a human health}

The impact of the microplastics on a human health is not recognized well. Some studies describe the issue. Due to reports on the presence of microplastics in marine organisms, toxicological studies of microplastics focused on this area. According to WHO analyzes, no human studies related to the consumption of microplastics with food have been identified (World Health Organization, 2019).

It is not clear if there is a difference between microplastic and natural small particles such as sediments or organic particles on the effects of human health (EASAC, 2020). Unfortunately, microplastics are contaminated with chemicals added or absorbed during the manufacturing processes. Those additives can be the source of physical and chemical toxicity (Lusher et al., 2017; Smith et al., 2018).

In Table 1, there are studies that investigate the plastic particle impact on human health.

Table 1. Plastic particle impact on human health (source: own study)

\begin{tabular}{|l|l|}
\hline \multicolumn{1}{|c|}{ Study } & \multicolumn{1}{c|}{ Results } \\
\hline $\begin{array}{l}\text { (Smith } \\
\text { et al., } \\
2018)\end{array}$ & $\begin{array}{l}\text { Consumed shellfish and other animals has are } \\
\text { he factor for human exposure. If there is toxicity } \\
\text { sourced from microplastics, it will dependent on } \\
\text { dose, size, polymer type, surface chemistry or } \\
\text { hydrophobicity. }\end{array}$ \\
\hline $\begin{array}{l}\text { (Deng } \\
\text { et al., } \\
2017)\end{array}$ & $\begin{array}{l}\text { Results point out accumulation of microplastic } \\
\text { in liver, gut and kidney. Authors describe } \\
\text { distribution pattern that depends strongly on the } \\
\text { microplastics particle size. }\end{array}$ \\
\hline $\begin{array}{l}\text { (Lu et al., } \\
2016)\end{array}$ & $\begin{array}{l}\text { Oxidative stress was diagnosed and reported after } \\
\text { exposure zebrafish to microplastics. }\end{array}$ \\
\hline
\end{tabular}

Routes of exposure to microplastics include inhalation, assimilation and dermal contact. Oxidative stress, inflammation and toxicity can be the cause of particle toxicity (Prata et al., 2020).

According to WHO report (2019) considering the potential human health arose from drinking-water contaminated with microplastics, there is not enough information to draw conclusions about the toxicity. That conclusion can be generalized to other sources of exposure. There are no reliable information that suggests it is a threat (World Health Organization, 2019). As a main recommendation, the authors suggest the need for quality-assured toxicological data combining the most common types of plastic materials and risks to human health. Moreover, a better understanding microplastics hazards should be done (World Health Organization, 2019).

\subsection{Dealing with the uncertain risk in the context of the food producers management systems}

Management is as old as humanity. It is assumed, however, that systematic research and management practices have existed for about 100 years. During this period, many theories were developed explaining how to manage the organization. It should be noted that none of the developed methods and techniques can be used in every situation (Kafel, 2017).

Due to the specificity of the food industry, there are two main and most popular groups of management systems used. First on based on the HACCP (Hazard Analysis and Critical Control Point) concept and can be implemented according to Codex Alimentarius, ISO 22001 standard or supplier requirements such as IFS (International Food Standard) or BRCGS (British Retail Consortium Global Standard). The main goal of these requirements is to ensure food safety. Second one is a quality management system complied with the ISO 9001 standard (Kafel \& Sikora, 2014). The main goal of ISO 9001 is (ISO, 2015a):

- to demonstrate ability to consistently provide product and services that are meeting customer and other statutory and regulatory requirements,

- enhance customer satisfaction.

Considering microplastics risks, both HACCP and ISO 9001 requirement have some common requirements. It is a risk assessment and fulfilment of regulatory requirements (ISO, 2015a, 2018). The problem with microplastics pollution in food product is that there are no direct obligatory requirements. Therefore, both systems do not enforces any actions in that matter.

According to EU regulations, considering the plastics and consequently microplastics, the circular economy is a supported concept (European Commision, 2015; Ünal et al., 2018). More circular economy is a concept in which value of goods such as products, materials and resources are maintained in the market for as long as possible. On the other hand the generation of waste should be minimized (EU, 2018; European Commision, 2015). According to Geissdoerfer and others (Geissdoerfer et al., 2017), circular economy is defined as a regenerative system in which the input of waste and resources, emissions and losses energy are minimized by slowing, closing and narrowing both material and energy loops. However, according to the authors the most complex as well as latest published definition of the circular economy is the one placed in the ISO 14009:2020 where it is described as systematic approach to the design of business models that are enabling the sustainable management of resources (ISO, 2020). The implementation of the circular economy in companies can be described by the " $3 \mathrm{R}$ principles": reduce, reuse and recycle (Ghisellini et al., 2016; Ünal et al., 2018). Despite common assumptions about circular economy, it is possible to identify various sectors of the economy in which practical measures related to the implementation of the circular economy practices will differ significantly. Managers of food sector organization, 
are now facing the new challenges that are resulting from the implementation of global action strategies developed at the international level. Circular economy strategy is one of that global movement, that is already implemented - as a part of The Green Deal - in the low requirements on the EU level (EU, 2019). For food manufacturers, the circular economy requirements are closely related to product packaging, sometimes even more than for food itself.

\section{Study description}

In the research, authors used a single case study that aims to thoroughly study one organization in within a research framework. The methodology used in the study was consistent with the description proposed by Yin (2009). The questionnaire survey includes questions grouped into five components, which were: introduction questions concerning the microplastic issue, HACCP risk assessment, customer requirements in the supply chain, R-PET law implementation and individual customers perspective. The case study was carried out in March 2020. For the study food sector manufacturing organization was chosen. Selection organization is one of the biggest polish food producer, specializing in beverages such as juices, nectars and drinks. It was assumed that the examined organizations should have implemented the HACCP system and voluntary management systems. The type of study was case study. Data collection of this study consist of two types, namely primary and secondary data. During the study, in the organization, representative of the leadership of the organization mainly - head of innovation for the company, has been interviewed. That was the source of the primary data. Organizations manuals and records such as HACCP risk matrix, quality and environmental policy and goals were also analyzed as a secondary data source. Advertising materials and information for consumers were used to supplement the research material. The study was conducted based on in advance developed script. The developed case scenario based on literature review and the interview was recorded.

Characteristics of studied organization:

- One of the biggest organization specialized in food production in Central and Eastern Europe.

- The leader on the market of non-alcoholic beverages (juices, nectars and drinks), and producer of instant products.

- Production is performed in 15 plants located in Central and Eastern Europe.

- Consolidated sales revenues for 2019 year reached PLN 5 billion.

As a market important player, organization has the capability to create innovative trends, including those related to minimizing the risk of microplastics in products.

\section{Results and discussion}

The analyzed company is producing wide variety of products intended for consumption. The beginnings of the company were associated with the production of juices and drinks, which are still an important element of the business to date. Microplastics is an important issue for that type of products. When asked about the general impression of that topic, the company top management representative said that there is a lot of information about the microplastics risk in media. However, there are no legal requirements in this field or good practices published by reliable sources. There are no specific organization activities or R\&D plans where the main focus is microplastics risks in products.

Considering the risk for food safety and HACCP implemented in organization, microplastics is not a risk that is asses in the HACCP risk assessment. There were no mentions about it in the organizations HACCP manuals. Of course, there are general risks related to packaging materials, mainly PET (polyethylene terephthalate), but without any details or references to microplastics. As a risk minimization method in organization in this area, the interviewed person indicated fulfilment of regulatory requirements for packaging materials. The laboratory tests for the global and specific migration is an obligatory document for all materials. The representative of the organization also pointed out that these types of laboratory tests are unable to detect small amounts of microplastic particles. On the other hand, this type of research is recognized by industry and regulators as sufficient to ensure food safety. Additional activities at the current state of knowledge seem to be economically unjustified. Asked about whether there were any tests to detect microplastics particles in their juices and drinks in the past, the answer was: no, there are no such regulatory and supplier requirements.

In that context, it could be concluded, that the importance of regulators legislating both at national and international level. Even if large and wealthy organizations perceive such problems through the economic calculation, there is no chance that other companies e.g. from the SME (small and medium enterprises) sector will conduct this type of research. This is in line with the studies that indicate the importance of legislation in food safety (Brough et al., 2016). It is especially important for the risks that take place "between" the legal requirements and the compliance/non-compliance outcome (Henson \& Heasman, 1998).

Considering the individual customers and the customers in the supply chain, such as supermarkets, the company representative said that until now, there were no registered questions, requirements or complaints related to the issue of microplastics. The records of the register of complaints confirm that statement. The main commercial networks that are buying their products or order production under their own brand have high quality and food safety expectations. According to the management representative both HACCP and ISO 9001 standards are required. This is in line with the research data describe in literature (Kafel \& Sikora, 2014). As critical requirements 
for the organization requested by commercial networks, manager pointed out:

- the reduction of packaging weight,

- implementation of new packaging materials e.g. RPET (25\% or recycled material till 2025 as it is describe in the directive (EU) 2019/904),

- changes in packaging design to facilitate their recycling.

All mentioned above actions are in line with the circular economy conception in the area of food packaging. They are also common with the quality management system requirements. According to ISO 9000 series of standard, meeting the expectations and needs of customers is one of the fundamentals of that philosophy (ISO, 2015a, $2015 b)$. The required challenges have according to studied organization representative two main obstacles. The first one is food safety that must be the priority, which is in line with HACCP requirements. R-PET in that contest can generate the microplastics risk, due to the lack of the reliable research results. The second problem are the costs of that change, that are transferred to the producer and consequently to the final customers.

The reduction of environment contamination and improvement of recycling efficiency for plastics packaging materials are the objectives of the European Commission's package designed to support circular economy (EASAC, 2020). The Commission also implements the waste circulation monitoring system under the directives and runs the Circular Plastics Alliance initiative. It is voluntary program aimed at, among others reducing the risk associated with microplastics. Managers were asked about that type of programs. They were not familiar with Circular Plastics Alliance program and have shown a great deal of caution in joining to it. As far as it is not a mandatory program (required by law or main customers) or the one that has economically justified advantages in a medium term perspective.

The reduction of packaging weight and changes in packaging design were the activities of a great value to the studied organizations. Unlike the uncertain threats arising from the presence of microplastics in products, the risks and costs associated with placing plastic packaging on the market are high. Moreover, that kind of activities causes reduction of plastic wastes and, as a consequence in a long term downturn of microplastics leak into the environment. It is important that the all planed and undertaken activities were closely related to economic calculation.

The last part of the study concerned the individual customers and their sensitivity to product safety and proenvironmental activities. Analysis of advertising materials and messages sent to the customers of the organization products showed no reference to microplastics. According to the reviewed person, there is an enormous gap between the customers declarations and real decisions while shopping. As an example, the glass bottles were pointed. In the customer declaration, it is the best and most desirable type of packaging. In contrary to the "sales numbers", that in general indicate the choice of lighter and cheaper juices and drinks in PET packaging by customers. It is important to mention that the organization sales the same brands/ products both in glass and PET bottles, so there is no way to explain it as premium branding beverages. Glass containers are still used for packaging, generally for products at the premium end of the market (Robertson, 2013). The management representative point out, that organic products, also produced by the organisation, which are usually perceived by customers as high quality products can be pack in PET containers. According to EU organic farming regulation, there are no restrictions for that type of packaging. So being in complacence with organic farming regulation (EU 834/2007) there is still among others a risk of occurrences of microplastics particles in the product.

Table 2. The main activities related to the reduction of the risk of microplastics in products with the relation to studied management systems (source: own study)

\begin{tabular}{|l|l|l|l|}
\hline \multicolumn{1}{|c|}{ Main actions } & \multicolumn{2}{|c|}{$\begin{array}{c}\text { Actions related to the scoop of } \\
\text { the system: }\end{array}$} \\
\cline { 2 - 4 } & $\begin{array}{c}\text { Circular } \\
\text { economy }\end{array}$ & $\begin{array}{c}\text { Quality } \\
\text { manage- } \\
\text { ment }\end{array}$ & $\begin{array}{c}\text { Food } \\
\text { safety } \\
\text { manage- } \\
\text { ment }\end{array}$ \\
\hline $\begin{array}{l}\text { Fulfilment of regulatory } \\
\text { requirements for } \\
\text { packaging materials }\end{array}$ & partially & partially & fully \\
\hline $\begin{array}{l}\text { Fulfilment of supplier } \\
\text { requirements }\end{array}$ & partially & fully & partially \\
\hline $\begin{array}{l}\text { Reduction of packaging } \\
\text { weight }\end{array}$ & fully & partially & not at all \\
\hline $\begin{array}{l}\text { Changes in packaging } \\
\text { design to facilitate their } \\
\text { recycling }\end{array}$ & fully & partially & not at all \\
\hline $\begin{array}{l}\text { Implementation of new } \\
\text { packaging materials e.g. } \\
\text { R-PET }\end{array}$ & fully & fully & partially \\
\hline $\begin{array}{l}\text { Introduction of organic } \\
\text { food products }\end{array}$ & partially & partially & not at all \\
\hline $\begin{array}{l}\text { Planned activities in the } \\
\text { field of communication } \\
\text { with the consumer }\end{array}$ & partially & partially & not at all \\
\hline
\end{tabular}

In Table 2, there were presented main activities related to the reduction of the risk of microplastics in products with the relation to studied management systems. Considering all actions it can be stated that most of them are related to the circular economy and quality management systems. The goals of HACCP and food safety management system was related to the identified activities to a small extend.

\section{Conclusions}

It seems that the issue of microplastics for studied company is a marginal problem that has not been given much 
attention so far. This is in line with the well know Pareto principle (80/20) where actions and measures should focus on problems that have the greatest impact on business.

Considering the unclear impact of microplastics on health and the benefits of using plastics, it is reasonable to take actions which certainly won't do any harm. Changes to reduce the use of the plastic increase the possibility of recycling and all other activities supporting the goals of circular economy seem to be the right course of action.

On the other hand, studied company is not willing to do in nearest future any actions that are above the regulatory and suppliers requirements. In that context, the role and importance of regulators legislating both at national and international level concerning the microplastics risks should be underlined. Circular economy can be a driver of benefits such as cost reduction. The economic calculation should encourage organizations to take measures to minimize the risk of microplastics food contamination.

It can be concluded that the concepts of circular economy, quality and food safety management systems in studied organization indirectly reduce the risks arising from the presence of microplastics in food products. On the other hand, there are no direct actions undertaken within the HACCP and ISO 9001 implemented management standards. The uncertain risks such as microplastics in the products and inadequate responses or lack of response could create or fuel social media crises. The problem of microplastics in connection with the analyzed management systems should be considered as one that is related with the scope of quality management and circular economy goals. Interestingly, the least number of actions were identified in relation of microplastics and the food safety management system. Therefore, it can be concluded that, taking into account the current state of knowledge, it is rather a marketing and environmental problem than a health one.

The main limitation of the study is that has been done in one international organization with its specific management culture. Moreover during the study only the point of view of top management was considered. It is recommended for the future research to investigate the subject in other organizations and with representatives of various levels of the organizations. This article is a preliminary study of microplastics risk in relation to quality and food safety as well as circular economy. In the future, deeper research can be done, for example about how to mitigate microplastics risk at the community level in terms of environmental management.

The other suggested future research can be aimed on the other food safety risks that are discussed by consumers and not fully verified by the authorities. Even if there is no reason to change the performance methods according to the food safety management system goals, there are still the quality management systems requirements, where consumers fears are important and some actions should be done.

\section{Funding}

This project has been financed by the Minister of Education and Science within the "Regional Initiative of Excellence" Programme for 2019-2022. Project no.: 021/ RID/2018/19. Total financing: 11897 131,40 PLN.

\section{Author contributions}

Conceptualization, P. K., P. N. and U. B.; methodology, P. K.; formal analysis, P. K., P. N. and U. B.; writing - original draft preparation, P. K.; writing - review and editing, P. K.; All authors have read and agreed to the published version of the manuscript.

\section{Disclosure statement}

The authors declare no conflict of interest.

\section{References}

Allen, S., Allen, D., Phoenix, V. R., Le Roux, G., Durántez Jiménez, P., Simonneau, A., Binet, S., \& Galop, D. (2019). Atmospheric transport and deposition of microplastics in a remote mountain catchment. Nature Geoscience, 12(5), 339-344. https://doi.org/10.1038/s41561-019-0335-5

Bergmann, M., Mützel, S., Primpke, S., Tekman, M. B., Trachsel, J., \& Gerdts, G. (2019). White and wonderful? Microplastics prevail in snow from the Alps to the Arctic. Science Advances, 5(8), eaax1157. https://doi.org/10.1126/sciadv.aax1157

Brough, M., Davies, B., \& Johnstone, E. (2016). Inside the black box of food safety: a qualitative study of 'non-compliance' among food businesses. Health Promotion Journal of Australia, 22(1), 10-14. https://doi.org/10.1071/HE15013

Cai, L., Wang, J., Peng, J., Tan, Z., Zhan, Z., Tan, X., \& Chen, Q. (2017). Characteristic of microplastics in the atmospheric fallout from Dongguan city, China: preliminary research and first evidence. Environmental Science and Pollution Research, 24(32), 24928-24935.

https://doi.org/10.1007/s11356-019-06979-x

Carpenter, E. J., Anderson, S. J., Harvey, G. R., Miklas, H. P., \& Peck, B. B. (1972). Polystyrene spherules in coastal waters. Science, 178(4062), 749-750.

Council Regulation (EC). (2007). No 834/2007 of 28 June 2007 on organic production and labelling of organic products and repealing Regulation (EEC), No 2092/91, OJ L 189, 20.7.2007 (pp. 1-23). https://doi.org/10.1126/science.178.4062.749

Cozar, A., Echevarria, F., Gonzalez-Gordillo, J. I., Irigoien, X., Ubeda, B., Hernandez-Leon, S., Palma, A. T., Navarro, S., García-de-Lomas, J., Ruiz, A., Fernández-de-Puelles, M. L., \& Duarte, C. M. (2014). Plastic debris in the open ocean. Proceedings of the National Academy of Sciences, 111(28), 10239-10244. https://doi.org/10.1073/pnas.1314705111

Dehghani, S., Moore, F., \& Akhbarizadeh, R. (2017). Microplastic pollution in deposited urban dust, Tehran metropolis, Iran. Environmental Science and Pollution Research, 24(25), 2036020371. https://doi.org/10.1007/s11356-017-9674-1

Deng, Y., Zhang, Y., Lemos, B., \& Ren, H. (2017). Tissue accumulation of microplastics in mice and biomarker responses suggest widespread health risks of exposure. Scientific Reports, 7(1), 46687. https://doi.org/10.1038/srep46687 
Dris, R., Gasperi, J., Mirande, C., Mandin, C., Guerrouache, M., Langlois, V., \& Tassin, B. (2017). A first overview of textile fibers, including microplastics, in indoor and outdoor environments. Environmental Pollution, 221, 453-458.

https://doi.org/10.1016/j.envpol.2016.12.013

Dris, R., Gasperi, J., Saad, M., Mirande, C., \& Tassin, B. (2016). Synthetic fibers in atmospheric fallout: A source of microplastics in the environment? Marine Pollution Bulletin, 104(1-2), 290-293. https://doi.org/10.1016/j.scitotenv.2018.01.092

EASAC. (2020). Packaging plastics in the circular economy. EASAC policy report 39. Jägerberg, Germany.

Ellen MacArthur Foundation (EMAF). (2015). Towards a circular economy: business rationale for an accelerated transition. https://www.ellenmacarthurfoundation.org/

EU. (2018). Communication from the Commission; A European Strategy for Plastic in a Circular Economy.

EU. (2019). Communication from the Commission to the European Parliament, the European Council, the Council, the European economic and social committee and the committee of the regions. The European Green Deal.

European Commision. (2015). Communication of 2.12.2015 on an EU action plan for the circular economy.

Gasperi, J., Wright, S. L., Dris, R., Collard, F., Mandin, C., Guerrouache, M., Langlois, V., Kelly, F. J., \& Tassin, B. (2018). Microplastics in air: Are we breathing it in? Current Opinion in Environmental Science \& Health, 1, 1-5.

https://doi.org/10.1016/j.coesh.2017.10.002

Geissdoerfer, M., Savaget, P., Bocken, N. M. P., \& Hultink, E. J. (2017). The circular economy - a new sustainability paradigm? Journal of Cleaner Production, 143, 757-768.

https://doi.org/10.1016/j.jclepro.2016.12.048

Ghisellini, P., Cialani, C., \& Ulgiati, S. (2016). A review on circular economy: The expected transition to a balanced interplay of environmental and economic systems. Journal of Cleaner Production, 114, 11-32. https://doi.org/10.1016/j.jclepro.2015.09.007

Goldstein, M. C., Rosenberg, M., \& Cheng, L. (2012). Increased oceanic microplastic debris enhances oviposition in an endemic pelagic insect. Biology Letters, 8(5), 817-820. https://doi.org/10.1098/rsbl.2012.0298

Henson, S., \& Heasman, M. (1998). Food safety regulation and the firm: understanding the compliance process. Food Policy, 23(1), 9-23. https://doi.org/10.1016/S0306-9192(98)00015-3

ISO. (2015a). ISO 9001:2015 Quality management systems. Requirements. International Organization for Standardization.

ISO. (2015b). ISO 9000:2015 Quality management systems. Fundamentals and vocabulary. International Organization for Standardization.

ISO. (2018). ISO 22000:2018 Food safety management systems. Requirements for any organization in the food chain. International Organization for Standardization.

ISO. (2020). ISO 14009:2020 Environmental management systems - Guidelines for incorporating material circulation in design and development. International Organization for Standardization.

Isobe, A., Iwasaki, S., Uchida, K., \& Tokai, T. (2019). Abundance of non-conservative microplastics in the upper ocean from 1957 to 2066. Nature Communications, 10(1), 417. https://doi.org/10.1038/s41467-019-08316-9

Isobe, A., Kubo, K., Tamura, Y., Kako, S., Nakashima, E., \& Fujii, N. (2014). Selective transport of microplastics and mesoplastics by drifting in coastal waters. Marine Pollution Bulletin, 89(1-2), 324-330.

https://doi.org/10.1016/j.marpolbul.2014.09.041
Isobe, A., Uchida, K., Tokai, T., \& Iwasaki, S. (2015). East Asian seas: A hot spot of pelagic microplastics. Marine Pollution Bulletin, 101(2), 618-623.

https://doi.org/10.1016/j.marpolbul.2015.10.042

Jamieson, A. J., Brooks, L. S. R., Reid, W. D. K., Piertney, S. B., Narayanaswamy, B. E., \& Linley, T. D. (2019). Microplastics and synthetic particles ingested by deep-sea amphipods in six of the deepest marine ecosystems on Earth. Royal Society Open Science, 6(2), 180667.

https://doi.org/10.1098/rsos.180667

Kafel, P. (2017). Integracja systemów zarządzania. Trendy, zastosowania, kierunki doskonalenia. Wydawnictwo UEK Kraków.

Kafel, P., \& Sikora, T. (2014). The level of management maturity in the Polish food sector and its relation to financial performance. Total Quality Management \& Business Excellence, 25(5-6), 650-663.

https://doi.org/10.1080/14783363.2013.876182

Kosuth, M., Mason, S. A., \& Wattenberg, E. V. (2018). Anthropogenic contamination of tap water, beer, and sea salt. PLOS ONE, 13(4), e0194970.

https://doi.org/10.1371/journal.pone.0194970

Li, L., Zhou, Q., Yin, N., Tu, C., \& Luo, Y. (2019). Uptake and accumulation of microplastics in an edible plant. Chinese Science Bulletin, 64(9), 928-934.

https://doi.org/10.1360/N972018-00845

Liu, E. K., He, W. Q., \& Yan, C. R. (2014). 'White revolution' to 'white pollution' - agricultural plastic film mulch in China. Environmental Research Letters, 9(9), 091001. https://doi.org/10.1088/1748-9326/9/9/091001

Lu, Y., Zhang, Y., Deng, Y., Jiang, W., Zhao, Y., Geng, J., Ding, L., \& Ren, H. (2016). Uptake and accumulation of polystyrene microplastics in Zebrafish (Danio rerio) and toxic effects in liver. Environmental Science \& Technology, 50(7), 4054-4060. https://doi.org/10.1021/acs.est.6b00183

Lusher, A. L., Burke, A., O’Connor, I., \& Officer, R. (2014). Microplastic pollution in the Northeast Atlantic Ocean: Validated and opportunistic sampling. Marine Pollution Bulletin, 88(12), 325-333. https://doi.org/10.1016/j.marpolbul.2014.08.023

Lusher, A., Hollman, P., \& Mendozal, J. (2017). Microplastics in fisheries and aquaculture: status of knowledge on their occurrence and implications for aquatic organisms and food safety. In FAO Fisheries and Aquaculture Technical Paper 615.

Nowicki, P., Kafel, P., Balon, U., \& Wojnarowska, M. (2020). Circular economy's standardized management systems. Choosing the best practice. Evidence from Poland. International Journal for Quality Research, 14, 1115-1128. https://doi.org/10.24874/IJQR14.04-08

Prata, J. C., da Costa, J. P., Lopes, I., Duarte, A. C., \& RochaSantos, T. (2020). Environmental exposure to microplastics: An overview on possible human health effects. Science of The Total Environment, 702, 134455. https://doi.org/10.1016/j.scitotenv.2019.134455

Robertson, G. L. (2013). Food Packaging. Principles and practice. CRC Press Taylor \& Francis Group.

Qi, Y., Yang, X., Pelaez, A. M., Huerta Lwanga, E., Beriot, N., Gertsen, H., Garbeva, P., \& Geissen, V. (2018). Macro- and micro- plastics in soil-plant system: Effects of plastic mulch film residues on wheat (Triticum aestivum) growth. Science of The Total Environment, 645, 1048-1056. https://doi.org/10.1016/j.scitotenv.2018.07.229

Schymanski, D., Goldbeck, C., Humpf, H. U., \& Fürst, P. (2018). Analysis of microplastics in water by micro-Raman spectroscopy: Release of plastic particles from different packaging into mineral water. Water Research, 129, 154-162. https://doi.org/10.1016/j.watres.2017.11.011 
Smith, M., Love, D. C., Rochman, C. M., \& Neff, R. A. (2018). Microplastics in seafood and the implications for human health. Current Environmental Health Reports, 5(3), 375-386. https://doi.org/10.1007/s40572-018-0206-Z

Steinmetz, Z., Wollmann, C., Schaefer, M., Buchmann, C., David, J., Tröger, J., Muñoz, K., Frör, O., \& Schaumann, G. E. (2016). Plastic mulching in agriculture. Trading short-term agronomic benefits for long-term soil degradation? Science of The Total Environment, 550, 690-705. https://doi.org/10.1016/j.scitotenv.2016.01.153

Ünal, E., Urbinati, A., \& Chiaroni, D. (2018). Managerial practices for designing circular economy business models. Journal of Manufacturing Technology Management, 30(3), 561-589. https://doi.org/10.1108/JMTM-02-2018-0061

Wesch, C., Elert, A. M., Wörner, M., Braun, U., Klein, R., \& Paulus, M. (2017). Assuring quality in microplastic monitoring: About the value of clean-air devices as essentials for verified data. Scientific Reports, 7(1), 5424. https://doi.org/10.1038/s41598-017-05838-4

World Health Organization. (2019). Microplastics in drinkingwater. Geneva, Switzerland. Licence: CC BY-NC-SA 3.0 IGO. Yin, R. K. (2009). Case study research. Design and methods (4th ed.). Sage Publications. 